\title{
PENGEMBANGAN MODEL PEMBELAJARAN BERBASIS KOMPETENSI BIDANG KELISTRIKAN DI SEKOLAH MENENGAH KEJURUAN
}

\author{
Riana T. Mangesa dan Dyah D. Andayani \\ Fakultas teknik Universitas Negeri Makassar \\ email: rianamangesa@yahoo.com
}

\begin{abstract}
Abstrak: Tujuan penelitian adalah mengembangkan model pembelajaran dan perangkat pembelajaran berbasis kompetensi terintegrasi pendidikan karakter di SMK. Penelitian ini termasuk jenis $R e$ search \& Development yang mengacu tahapan Borg dan Gall (1983), yaitu yang terdiri atas analisis kebutuhan, perancangan pengembangan, validasi ahli dan revisi, uji coba, dan tahap implementasi. Data berupa data kuantitatif dan kualitatif yang diperoleh lewat angket. Teknik analisis data yang digunakan adalah statistik deskriptif dan statistik nonparametrik, yaitu Kruskall Wallis yang penghitungannya memakai SPSS. Hasil penelitian berupa produk pengembangan perangkat pembelajaran bidang kelistrikan yang berupa modul, media, dan penilaian pencapaian kompetensi (rubrik penyekoran). Hasil pengembangan memenuhi tuntutan validitas, pencapaian kompetensi dalam proses pembelajaran yang dipergunakan secara keseluruhan tinggi, guru memberi skor penilaian melalui pencapai kompetensi sesuai kriteria dalam rubrik penyekoran terhadap ketiga aspek kompetensi, yaitu aspek kognitif, afektif, dan psikomotorik. Penilaian keefektifan pembelajaran secara menyeluruh menunjukkan bahwa siswa dan guru memberikan tanggapan secara aktif dan mencapai tujuan pembelajaran.
\end{abstract}

Kata Kunci: pengembangan model penilaian, pembelajaran berbasis kompetensi, rubrik penyekoran, $S M K$

\section{DEVELOPING A COMPETENCE-BASED INSTRUCTIONAL MODEL IN THE ELECTRICAL FIELD IN VOCATIONAL SCHOOLS}

\begin{abstract}
This study was aimed to develop a competence-based instructional model integrated with character education in vocational schools. This study belonged to the Research and Development study using the stages as developed by Borg and Gall (1983): a needs analysis, developmental design, expert validation and revision, try-out, and implementation stages. The data were in the form of quantitative and qualitative data obtained through questionnaires. The data were analyzed using the descriptive statistics and non-parametric statistics, that is, Kruskall Wallis with the help of SPSS program. The findings showed that the developed product of the instructional kits in the electrical field in the form of a modulle, media, competence achievement assessment (scoring rubric) had fulfilled the validity requirement. The achievement of the competence in the instructional process was as a whole considered as high. Teachers gave the scores based on the criteria in the scoring rubric in the three competence aspects, that is, cognitive, affective, and psychomotoric domains. The assessment of the instructional effectiveness showed that students and teachers responded actively and achieved the instructional objectives.
\end{abstract}

Keywords: instructional model, scoring rubric, vocational schools

\section{PENDAHULUAN}

Adanya pergeseran penilaian masyarakat pengguna terhadap kualitas pendidikan kejuruan dengan isu ketidaksesuaian (mismacth) sudah menjadi isu utama dalam polemik antara dunia pendidikan dan dunia kerja, baik di tingkat pusat maupun di daerah. Permasalahan tersebut menunjukkan lemahnya sistem pendidik- 
an di beberapa sekolah menengah kejuruan (SMK), yang berdampak pada rendahnya kompetensi keahlian yang dimiliki peserta didik dan kurangnya nilai-nilai karakter dalam proses belajar. Penyesuaian kebutuhan kompetensi dunia kerja dan pengintegrasian pembentukan karakter memerlukan model pembelajaran yang didesain sesuai alasan fenomena pengembangan kurikulum 2013.

Secara empiris gambaran tentang rendahnya penguasaan keterampilan dunia kerja kelistrikan dinyatakan oleh pengurus Asosiasi Profesionalis Elektrikal Indonesia (APEI) (Muddassir, 2013), kurangnya jumlah tenaga kerja bersertifikat kelistrikan dikarenakan sistem pendidikan yang berjalan tidak sinkron dengan kebutuhan industri yang ada. Masalah ini berkaitan dengan pembelajaran di SMK pada kompetensi keahlian teknik instalasi listrik, yang terbagi dalam beberapa spektrum Standar Kompetensi dan Kompetensi Dasar (SKKD). Didukung hasil survei awal pada SMK negeri dan swasta di Makassar, ditemukan bahwa lemahnya sistem pembelajaran dipengaruhi oleh belum terciptanya link and match karena dukungan pemerintah kurang, dan minimnya perangkat pembelajaran yang dimiliki. Kondisi ini mendorong pentingnya inovasi dalam sistem pembelajaran untuk mengembangkan model pembelajaran berbasis kompetensi dunia kerja.

Sesuai dengan tujuan pendidikan SMK yang harus mampu memenuhi tuntutan kualitas dan relevansi dalam menghadapi persaingan global, seharusnya dapat diwujudkan dalam peningkatan kecerdasan, pengetahuan, kepribadian, akhlak mulia, serta keterampilan untuk hidup mandiri. Tujuan tersebut dapat memberi makna bahwa tugas pendidikan kejuruan adalah mempersiapkan sumber daya manusia yang berkarakter dan memiliki kompetensi, kemandirian, kemampuan kerja sesuai bidang keahliannya.

Sehubungan dengan pemberlakuan kurikulum 2013 dan adanya Undang-Undang No. 20 Tahun 2003 tentang Sistem Pendidikan Nasional dan Peraturan Pemerintah No. 19 Tahun 2005 tentang SNP, maka pengembangan sistempenilaian sebagai akibat dari Kurikulum 2013 yang berimplikasi terhadap sistem pembelajaran berbasis kompetensi dan bernilai karakter sangat mendesak dilakukan. Evaluasi penilaian skor pencapaian kompetensi dapat dilakukan selama pembelajaran berlangsung dan setelah pembelajaran usai dilaksanakan.

Sistem evaluasi hasil belajar di SMK yang bertujuan untuk menilai dan mengukur tingkat kemampuan peserta didik, di samping memahami perubahan-perubahan yang terjadi pada keseharian peserta didik, juga mengacu pada Permendikbud No. 65 Tahun 2013 tentang Standar Proses Pendidikan Dasar dan Menengah tentang proses pembelajaran yang dipandu dengan kaidah-kaidah pendekatan saintifik. Pencapaian penguasaan kompetensi mengacu pada Standar Nasional Pendidikan (SNP) sebagai dasar penilaian, yang dapat diukur dari pencapaian kecakapan yang lebih tinggi. Penilaian dalam model pembelajaran berbasis kompetensi yang dikembangkan, lebih menekankan pada pencapaian kompetensi peserta didik aspek kognitif (K), afektif (A) dan psikomotorik $(\mathrm{P})$, yang dirancang sebagai acuan dalam memberikan skor atas kemampuan peserta didik terhadap materi yang dipelajarinya.

Implementasi pembelajaran dan penilaian dalampendidikan karakter yang menjadi ciri khas Kurikulum 2013 sejalan dengan pemahaman terhadap terminologi yang dipergunakanDavid Kerr dalam menjelaskan isi dan modus Citizenship Education (1999), yaitu proses pembelajaran pendidikan karakter, hendaknya dilakukan secara inklusif pada semua mata pembelajaran di kelas, keluarga, dan masyarakat. Pengembangan pembelajaran yang dimaksudkan untuk menghindarkan pendidikan karakter dari sifat yang eksklusif, yaitu upaya pembinaan karakter hanya dilakukan pada mata pelajaran tertentu dan program pendidikan lain tidak menyentuhnya. Berdasarkan pemahaman tersebut, maka pengintegrasian pendidikan karakter kedalam semua materi pembelajaran seharusnya dilakukan dalam rangka mengembangkan kegiatan proses belajar sehingga substansi nilai sesungguhnya secara eksplisit atau implisit sudah ada dalam rumusan kompetensi (SKL,SK dan KD). Karena itu, diperlukan ke- 
pastian bahwa internalisasi sudah dilakukan pada setiap materi ajar yang memiliki dampak instruksional dan dampak pengiring pembentukan karakter.

Penerapan pendekatan belajar dalam $\mathrm{Ku}$ rikulum 2013 menarik untuk dikembangkan dan dielaborasi lebih lanjut. Nilai-nilai karakter dapat ditumpangkan dalam rencana pelaksanaan pembelajaran(RPP) karena pembentukan nilainilai karakter dapat direncanakan melalui rekayasa faktor lingkungan dan dilakukan dengan pendekatan kontekstual pada mata pelajaran praktik. Prosesnya dapat bervariasi disesuaikan RPP dan metode yang dipersiapkan. Melalui RPP dapat direncanakan nilai-nilai karakter yang harus ditumpangkan dalam materi ajar dengan mengusahakan agar peserta didik termotivasi, dapat mengenal dan menerima nilainilai karakter dalam setiap tujuan pencapaian pembelajaran. Karena itu, secara bertanggung jawab peserta didik akan menetapkan keputusan yang diambilnya melalui tahapan mengenal, menilai, bersikap, selanjutnya mampu berkeyakinan pada diri peserta didik tersebut.

Model pembelajaran yang dikembangkan dalam penelitian ini adalah model pembelajaran berbasis kompetensi bidang kelistrikan terintegrasi pendidikan karakter di SMK. Sistem pembelajaran di SMK sebagian sudah menerapkan Kurikulum 2013 sehingga terjadi beberapa perubahan mendasar pada perangkat pembelajaran mulai dari sillabus, RPP, metode pembelajaran sampai pada sistem evaluasi dan penilaian hasil belajar. Terkait dengan pemahaman perangkat pembelajaran yang dapat dilihat dari dua aspek, yaitu: (1) aspek mengajar guru, yaitu sejauhmana proses pembelajaran dapat terlaksana; dan (2) aspek hasil belajar peserta didik, sejauh mana tujuan pelajaran yang diinginkan tercapai melalui proses pembelajaran (Muchith, 2008:33).

Pengembangan model pembelajaran mengacu pada beberapa ahli, sesuai pendapat berbagai pakar bidang pembelajaran. Dick dan Carey (2005:6-8) mengemukakan bahwa ada sepuluh langkah untuk pengembangan model desain pembelajaran, yang meliputi: (1) identity instructional goals; (2) conducting a goal analysis; (3) analyze learners and contexts;(4) write performance objectives; (5) develop assessment instruments; (6) develop instructional strategy; (7) develop and select instructional materials;(8) design and conduct formative evaluation; (9) revise instruction; and (10) design and conduct summative evaluation. Kesepuluh langkah model Dick and Carey menunjukan hubungan yang sangat jelas dan tidak terputus antara langkah yang satu dengan lainya, sistemnya sangat ringkas, tetapi isinya padat dan jelas dari satu urutan keurutan berikutnya.

Berdasarkan pada asumsi bahwa pembelajaran merupakan sistem yang terdiri atas beberapa unsur, yaitu masukan, proses dan hasil, oleh karena itu terdapat tiga jenis evaluasi, yaitu evaluasi masukan, proses dan hasil pembelajaran. Dengan demikian, dalam pembelajaran praktik pada model yang dikembangkan yang bertujuan mengarahkan peserta didik mencapai kompetensi yang bernilai karakter, jenis evaluasi yang dikembangkan adalah evaluasi hasil pembelajaran. Tujuan evaluasi hasil pembelajaran adalah untuk melakukan pengukuran hasil belajar sebagai pencapaian kompetensi, dalam hal ini adalah penguasaan kompetensi setiap individu dengan memberi penilaian pada pencapaian kompetensi. Hasil penelitian pengembangan model pembelajaran berbasis kompetensi terintegrasi pendidikan karakter, evaluasi hasil pembelajaran dikembangkan untuk penilaian hasil pembelajaran praktik memasang instalasi listrik.

Mengacu pada beberapa bentuk penilaian berbasis kompetensi, penilaian dirancang dalam bentuk rubrik penyekoran yang mencakup tugas, keterampilan, sikap, dan apresiasi yang harus dimiliki peserta didik dalam melaksanakan tugas pembelajaran sesuai dengan pekerjaan tertentu. Rubrik adalah suatu hirarki dari standar yang digunakan untuk menskor unjuk kerja pencapaian kompetensi peserta didik. Rubrik memuat daftar kriteria kemampuan pencapaian kompetensi yang diukur pada setiap tugas-tugas pembelajaran. Finch \& Crunklinton (1999:258) menyebutkan bahwa kemampuan tersebut harus sejalan dengan kompetensi yang bersifat individu maupun sosial. Oleh ka- 
rena itu, model pembelajaran berbasis kompetensi dirancang untuk menguasai sikap, pengetahuan, keterampilan.

\section{METODE}

Penilaian hasil pembelajaran yang dirancang dalam bentuk rubrik penyekoran adalah satu dari produk perangkat pembelajaran yang dikembangkan dalam penelitian pengembangan model pembelajaran berbasis kompetensi terintegrasi pendidikan karakter. Oleh karena itu, penelitian initermasukjenis penelitian pengembangan pendidikan atau Research \& Developmen (R\&D), yaitu mengacu pada tahapan model Borg dan Gall (1983).

Sesuai tahapan model penelitian R\&D, tahapan penelitian dibagi dalam dua tahap yaitu, tahap prapengembangan dan pengembangan. Tahap prapengembangan dengan luarannya berupa prototipe model yang sudah divalidasi dan direvisi melalui FGD. Untuk tahap pengembangan dilakukan ujicoba skala kecil, uji skala besar, dan kegiatan implementasi. Revisi dilakukan sesuai informasi pengamat. Pada kegiatan implementasi dilakukan tindakan penilaian hasil belajar untuk mengevaluasi kemampuan peserta didik dengan menggunakan rubrik penyekoran sebagai alat ukur tingkat pencapaian kompetensi peserta didik.
Tahapan dalam penelitian $R \& D$ yang berupa langkah penelitian untuk mengembangkan produk (Sukmadinata, 2008:164-165), mengacu pada tahapan penelitian berdasarkan Borg \& Gall (1983:784-785) yang dimodifikasi menjadi lima tahapan, yaitu: (1) tahap analisis kebutuhan; (2) tahap perancangan pengembangan; (3) tahap validasi ahli dan revisi; (4) tahap uji coba; dan (5) tahap implementasi. Tahapan yang dimaksud ditunjukkan pada Gambar 1.

Data penelitian berupa data kualitatrif dan kuantitatif. Data kualitatif diperoleh dari instrumen angket pada tingkatan-tingkatan pertama hingga ketiga, mulai dari tahap identifikasi kebutuhan kompetensi dunia kerja kelistrikan, dan identifikasi kebutuhan pembelajaran di sekolah. Data kuantitatif diperoleh pada uji validasi dan selama uji coba berlangsung, yaitu pada penilaian pengamatan saat proses pelaksanaan uji coba perangkat model.

Analisis data dilakukan secara deskriptif kualitatif, yaitu mendeskripsikan hasil pengembangan, respons validator, dan hasil uji coba dengan memberikan narasi yang logis sesuai dengan kepentingan penelitian. Komputasi analisis data dilakukan dengan menggunakan bantuan paket program Microsoft Excel dan paket Program SPSS for Windows.

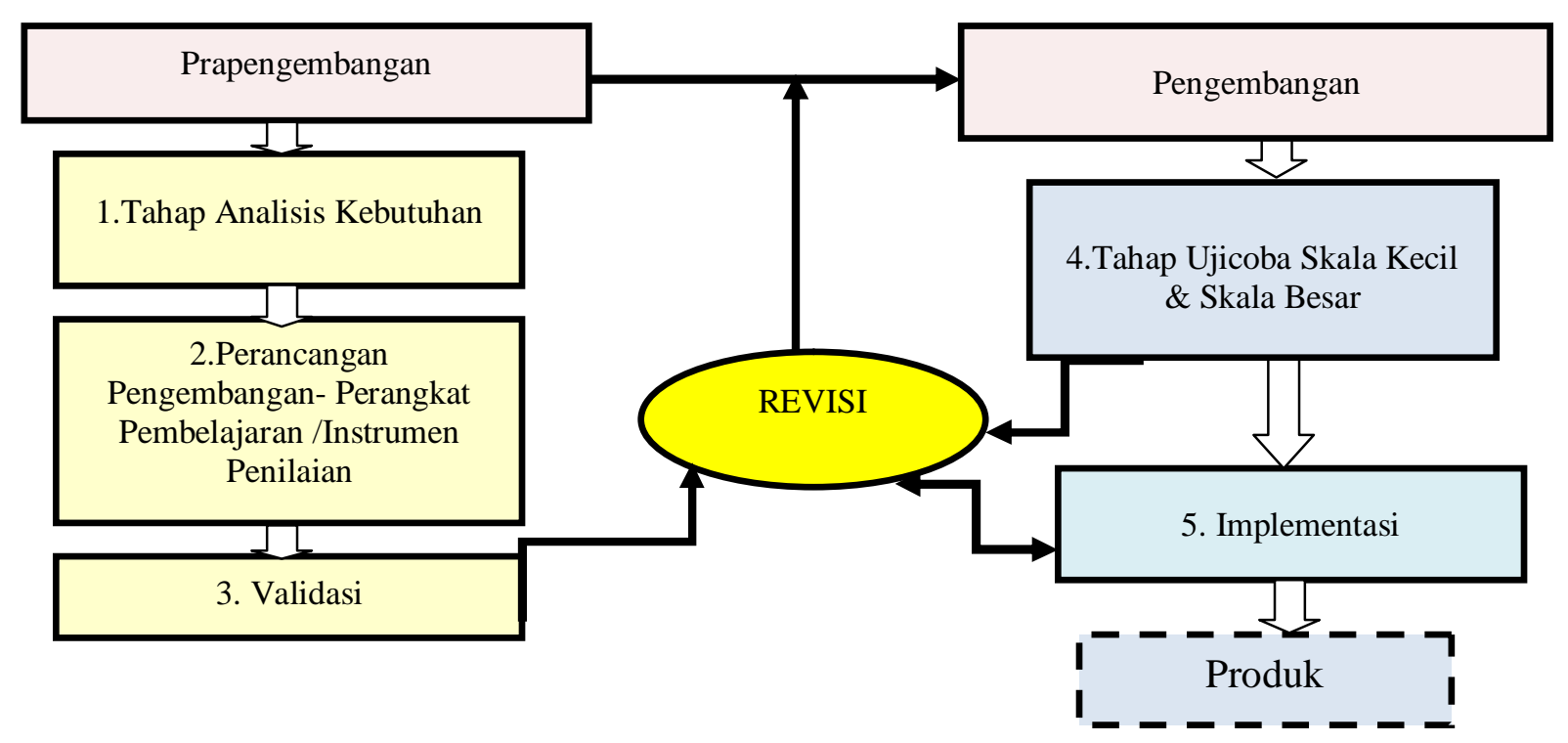

Gambar 1. Tahapan Penelitian dan Pengembangan

Skala penilaian menggunakan skala Likert dengan skala 1-4 dengan mengacu pada
Azwar (2010:109) yang dimodifikasi pada Tabel 1 . 
Tabel 1. Standar Konversi Data Kuantitatif ke Data Kualitatif

\begin{tabular}{|c|c|c|}
\hline Rerata Skor & Kriteria & Keteraangan \\
\hline $3,5 \leq M \leq 4,0$ & Sangat Baik & $\begin{array}{l}\text { Dapat dipergunakan } \\
\text { tanpa revisi }\end{array}$ \\
\hline $2,5 \leq M<3,5$ & Baik & $\begin{array}{l}\text { Dapat dipergunakan } \\
\text { dengan sedikit } \\
\text { revisi }\end{array}$ \\
\hline $1,5 \leq M<2,5$ & Cukup Baik & $\begin{array}{l}\text { Dapat dipergunakan } \\
\text { dengan banyak } \\
\text { revisi }\end{array}$ \\
\hline $0,0 \leq M<1,5$ & Kurang Baik & $\begin{array}{l}\text { Tidak dapat } \\
\text { dipergunakan }\end{array}$ \\
\hline
\end{tabular}

Keterangan: $\mathrm{M}=$ rerata skor untuk setiap aspek yang dinilai

Kriteria yang digunakan untuk memutuskan bahwa instrumen dapat dipergunakan adalah apabila rerata (M) hasil penilaian untuk keseluruhan aspek minimal berada dalam kriteria "Sangat Baik". Jika kurang dari itu, dilakukan revisi berdasarkan saran para validator dengan melihat kembali aspek-aspek yang nilainya kurang. Selain mempertimbangkan aspek validitas, kepraktisan dinyatakan pula melalui butir-butir instrumen yang diamati pada saat proses pembelajaran berlangsung. Untuk mengukur tingkat kesepakatan antarpenilai (interrater reliability) terhadap hasil penilaian/validasi instrumen penelitian, dianalisis dengan statistik SPSS yakni Kruskall Wallis.

\section{HASIL DAN PEMBAHASAN}

\section{Kegiatan Prapengembangan}

Kegiatan tahapan ini meliputi hal-hal sebagai berikut. Tahap analisis kebutuhan: ditemukan blue print matriks kompetensi dalam pembelajaran praktik yang dibutuhkan oleh SMK bidang keahlian teknik instalasi tenaga listrik. Kegiatan ini dilakukan dengan mengidentifikasi kompetensi pemasangan instalasi listrik bangunan sederhana melalui workshop yang dilaksanakan bekerjasama dengan tim asesor bidang kelistrikan dari Asosiasi Kontraktor Listrik Indonesia (AKLI) Cabang Makassar. Selain itu, juga mengidentifikasi kompetensi melalui pengkajian dalam focus grup discussion (FGD) bersama praktisi pendidikan, yaitu guru-guru SMK dan dosen D3 bidang kelistrikan.

Tahap perancangan pengembangan berupa kegiatan pembuatan prototipe awal model dan perangkat pembelajaran. Komponen hasil pengembangan meliputi standar kompetensi dan kompetensi dasar (SKKD); perangkat pembelajaran (modul, RPP, media, rubrik penyekoran); dan instrumen penilaian.

Tahap validasi ahli dan revisi: validasi internal secara konseptual terhadap prototipe awal yang dimintakan kepada para validator. Validator terdiri atas tiga dosen pakar pendidikan dan praktisi pendidikan (bidang pendidikan teknologi kejuruan, evaluasi, materi di bidang teknik kelistrikan). Hasil dan saran-saran validator dijadikan masukan untuk merevisi prototipe. Rekomendasi validator menjadi informasi pemenuhan kriteria validitas model dan perangkat yang dikembangkan.

\section{Kegiatan Pengembangan}

Pada tahap pengembangan produk dilakukan uji coba produk dengan subjek (1) peserta didik SMK bidang keahlian teknik instalasi kelas XI yang sedang mengikuti mata pelajaran pemasangan instalasi listrik; dan (2) guru-guru bidang keahlian instalasi listrik. Kedua unsur subjek coba tersebut selalu terlibat dalam prosedur pengembangan, dimulai dari uji I pada kelompok skala kecil, sampai pada uji II pada kelompok skala besar yang diperluas. Uji coba produk dimaksudkan untuk mengumpulkan data tentang kualitas produk.

Kelanjutan hasil validasi internal yang telah direvisi, ditindaklanjuti pada dua kali tahapan, yaitu uji coba skala kecil dan skala besar. Uji coba skala kecil dilakukan pada 15 peserta didik yang dimaksudkan untuk mengidentifikasi permasalahan untuk merevisi dan mengetahui kualitas perangkat pembelajaran. Uji coba skala besar dilakukan pada peserta didik dalam satu kelas yang dimaksudkan untuk mengumpulkan data tentang peningkatan kualitas perangkat pembelajaran. 


\section{Tahap Implementasi}

Untuk mengetahui efektivitas perangkat pembelajaran dilakukan tindakan pembelajaran yang sesungguhnya pada empat kali pertemuan mengacu pada pencapaian satu kompotensi dasar (KD) dalam memasang instalasi listrik bangunan sederhana. Keefektifan pembelajaran di- lihat dari dua aspek, yaitu aspek pelaksanaan pembelajaran oleh guru dan aspek capaian hasil belajar peserta didik. Selanjutnya, kedua aspek tersebut dinilai dengan mempergunakan instrumen yang telah disiapkan. Hasil penilaian yang dimaksud ditunjukkan pada Tabel 1 .

Tabel 1: Rangkuman Penilaian Aktivitas Guru

\begin{tabular}{|c|c|c|c|c|c|c|c|}
\hline \multirow{2}{*}{\multicolumn{2}{|c|}{$\begin{array}{l}\text { Aspek yang Dinilai } \\
\text { Pengamat }(\mathrm{P})\end{array}$}} & \multicolumn{4}{|c|}{ Hasil Penilaian/Pertemuan Ke- } & \multirow{2}{*}{$\begin{array}{l}\text { Rerata } \\
\text { Aspek }\end{array}$} & \multirow{2}{*}{ Kategor } \\
\hline & & 1 & 2 & 3 & 4 & & \\
\hline & $\mathrm{P} 1$ & 3.00 & 3.40 & 3.80 & 3.96 & & \\
\hline \multicolumn{8}{|l|}{ Aspek } \\
\hline \multirow{3}{*}{ Persiapan } & $\mathrm{P} 2$ & 3.00 & 3.60 & 3.80 & 3.94 & \multirow[t]{3}{*}{3,58} & Sangat \\
\hline & Rerata & 3.00 & 3.50 & 3.80 & 4.00 & & Baik \\
\hline & P1 & 3.00 & 3.56 & 3.67 & 4.00 & & \\
\hline Aspek & P2 & 3.00 & 3.58 & 3.67 & 3.98 & \multirow{3}{*}{3,57} & Sangat \\
\hline \multirow{2}{*}{$\begin{array}{l}\text { kegiatan } \\
\text { Inti }\end{array}$} & Rerata & 3.00 & 3.58 & 3.67 & 4.00 & & Baik \\
\hline & P1 & 300 & 350 & 375 & 3.98 & & \\
\hline \multicolumn{6}{|l|}{ Aspek } & \multirow[t]{3}{*}{3,56} & \\
\hline \multirow[t]{2}{*}{ Penutup } & P2 & 3.00 & 3.50 & 3.75 & 3.98 & & Sangat \\
\hline & Rerata & 3,00 & 3,50 & 3,75 & 4,00 & & Baik \\
\hline \multicolumn{8}{|c|}{ Penilaian Rerata dan Kriteria secara keseluruhan $=3,61$ (Sangat Baik) } \\
\hline
\end{tabular}

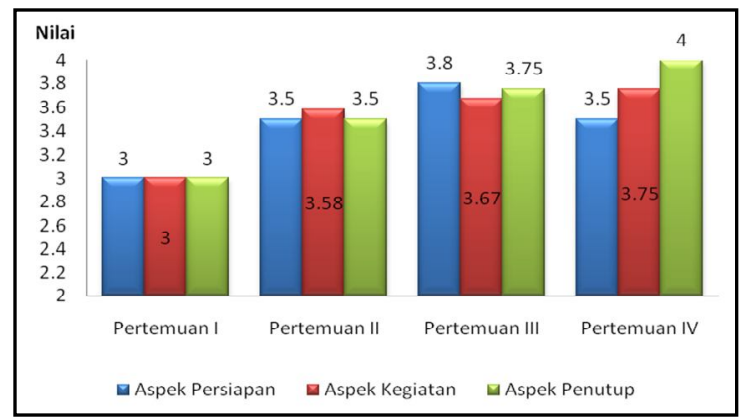

Gambar 1. Kecendrungan Peningkatan Aktivitas Guru

Hasil penilaian pengamat menunjukkan bahwa peningkatan aktivitas Guru dalam pelaksanaan pembelajaran dapat dikategorikan sangat baik, pada setiap pertemuan. Gambar 1 menunjukkan nilai rerata yang tersebar pada masing-masing aspek, mulai dari aspek persiapan pada tiap pertemuan dan kegiatan inti.

Gambaran kecendrungan peningkatan hasil penilaian secara keseluruhan terhadap akti- vitas guru selama berlangsungnya uji coba I dan II. Aktivitas guru dalam keterlaksanaan tahapan pembelajaran (sintaks pembelajaran) pada uji coba I dan II sudah cenderung meningkat dari pertemuan pertama sampai pada pertemuan keempat.

Rangkuman hasil evaluasi aktivitas siswa secara keseluruhan ditunjukkan pada Tabel 2. Hasil evalusi dari ketiga aspek menunjukkan bahwa untuk dua sekolah aktivitas siswa dalam proses pembelajaran memiliki kriteria sangat baik.

Penilaian pengujian konsistensi antarkedua pengamat sebagai sumber data mengunakan analisis statistik SPSS, yakni Kruskall Wallis. Melalui komputasi SPSS dilakukan pengujian perbedaan rerata hasil penilaian pada kelompok subjek coba. Rangkuman analisis tersebut dapat dilihat pada Tabel 3 dan Tabel 4. 
Tabel 2. Rangkuman Hasil Penilaian Aktivitas Siswa

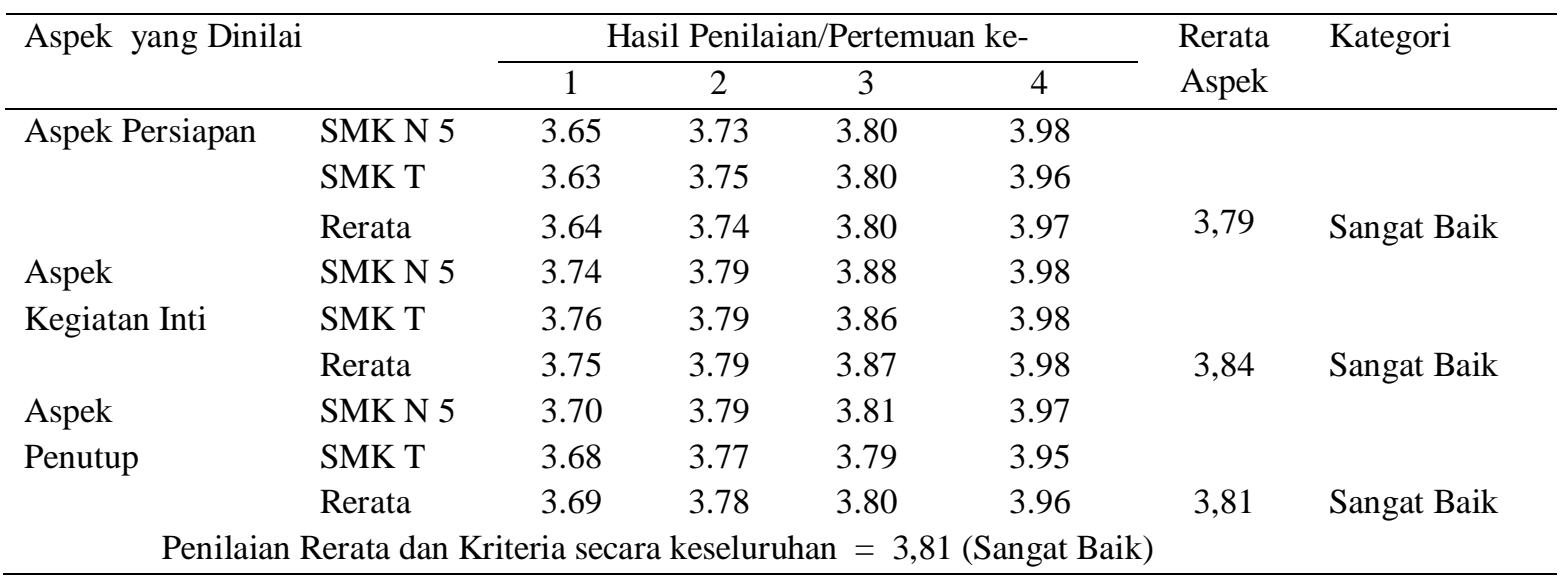

Tabel 3. Hasil Uji Konsistensi Pengamatan Aktivitas Guru

\begin{tabular}{lrr}
\hline & PSMKN5 & \multicolumn{2}{c}{ PSMKT } \\
\hline Chi-Square & 1.249 & 4.545 \\
Df & 2 & 2 \\
Asymp. Sig. & .535 & .103 \\
\hline
\end{tabular}

a . Kruskal Wallis Test

b. Grouping Variable: Aspek dalam Aktivitas Guru

Hasil pengamatan kepada guru dapat menunjukkan bahwa kedua hasil pengujian menunjukkan tidak ditemukan adanya perbedaan, artinya terdapat konsistensi antardua kelompok penilai di dua sekolah.

Pengujian yang dilakukan pada penilaian kelompok siswa dalam proses pembelajaran untuk melihat keaktifan siswa, yaitu kelompok nilai di SMKN 5 dan di SMKT. Tabel 4 menunjukkan hasil penilaian pada kelompok aktivitas peserta didik konsisten karena tidak ditemukan adanya perbedaan.

Tabel 4. Hasil Uji Konsistensi Pengamatan Aktivitas Siswa

\begin{tabular}{lrr}
\hline & PSMKN5 & PSMKT \\
\hline Chi-Square & .905 & 4.321 \\
Df & 2 & 2 \\
Asymp. Sig. & .636 & .115 \\
\hline
\end{tabular}

a. Kruskal Wallis Test

b. Grouping Variable: Aspek pada Aktivitas Siswa

Jadi, terdapat konsistensi antara dua kelompok penilai di dua sekolah. Hal ini membe- rikan kesimpulan bahwa aktivitas guru dan siswa dalam proses pembelajaran adalah konsisten sehingga evaluasi penilaian hasil belajar dapat dilakukan dengan menggunakan perangkat pembelajaran (rubrik penyekoran) yang sudah divalidasi oleh validator. Sebagai acuan dalam memberikan skor atas pencapaian kompetensi siswa, digunakan kriteria pada tiga ranah kognitif (30\%) Tabel 5, afektif (35\%) Tabel 6, dan psikomotorik (35\%) Tabel 7.

Melalui indikator yang dinilai dan mengacu pada matriks kompetensi yang dibutuhkanuntuk pencapaian Kompetensi Dasar (KD). Penilaian Rubrik Penyekoran: Skor Tertinggi $=$ 3, Skor Baik= 2 dan Skor Kurang $=1$

Tabel 5. Rubrik Penyekoran pada Ranah Kognitif (30\%)

\begin{tabular}{|c|c|c|}
\hline $\begin{array}{c}\text { Indikator } \\
\text { yang dinilai }\end{array}$ & Skor & Kriteria \\
\hline $\begin{array}{l}\text { Pemahaman } \\
\text { prosedur, per- } \\
\text { aturan Kese- } \\
\text { lamatan Ke- }\end{array}$ & 3 & $\begin{array}{l}\text { Sangat baik, jika semua pe- } \\
\text { kerjaan dapat dilakukan tepat } \\
\text { dan benar sesuai prosedur K3 } \\
\text { dan lingkungan kerja. }\end{array}$ \\
\hline $\begin{array}{l}\text { sehatan Kerja } \\
\text { (K3) dan ling- } \\
\text { kungan kerja }\end{array}$ & 2 & $\begin{array}{l}\text { Baik, jika sebagian besar pe- } \\
\text { kerjaan dapat dilakukan benar } \\
\text { sesuai prosedur K3 dan ling- } \\
\text { kungan kerja }\end{array}$ \\
\hline & 1 & $\begin{array}{l}\text { Kurang, jika hanya sebagian } \\
\text { kecil pekerjaan dapat dilaku- } \\
\text { kan dengan benar sesuai pro- } \\
\text { sedur dan lingkungan kerja. }\end{array}$ \\
\hline
\end{tabular}


Tabel 6. Rubrik Penyekoran pada Ranah Afektif (35\%)

\begin{tabular}{lrl}
\hline \multicolumn{1}{c}{$\begin{array}{c}\text { Indikator } \\
\text { yang Dinilai }\end{array}$} & Skor & \multicolumn{1}{c}{ Kriteria } \\
\hline $\begin{array}{l}\text { Kejujuran da- } \\
\text { lam menggu- } \\
\text { nakan standar } \\
\text { dan peraturan }\end{array}$ & 3 & $\begin{array}{l}\text { Sangat baik, jika semua stan- } \\
\text { dar dan peraturan kelistrikan } \\
\text { dalam proses kerja diterapkan } \\
\text { kelistrikan. }\end{array}$ \\
& $2 \begin{array}{l}\text { dengan jujur } \\
\text { Baik, jika sebagian besar stan- } \\
\text { dar dan peraturan kelistrikan } \\
\text { dalam proses kerja diterapkan } \\
\text { dengan jujur } \\
\text { Kurang, jika sebagian kecil } \\
\text { standar dan peraturan kelistrik- } \\
\text { an dalam proses kerja diterap- } \\
\text { kan dengan jujur. }\end{array}$ \\
\hline
\end{tabular}

\section{Tabel 7. Rubrik Penyekoran pada Ranah Kognitif (35\%)

\begin{tabular}{l}
$\begin{array}{l}\text { Indikator yang } \\
\text { dinilai }\end{array}$ \\
\hline
\end{tabular}

Sangat baik, jika tepat mene-

Ketepatan da- 3 rapkan semua peraturan kelislam menghi- trikan dalam menghitung batung jumlah han/alat yang digunakan.

bahan/alat yang diguna-

kan sesuai peraturan
2 Baik, jika tepat menerapkan sebagian besar peraturan kelistrikan dalam menghitung bahan/alat yang digunakan.

1 Kurang, jika menerapkan sebagian peraturan kelistrikan dalam menghitung bahan/alat yang digunakan.
Setelah melakukan penyekoran, guru menganalisis data hasil penilaian, merumuskan pemberian penghargaan kepada siswa (nilai) sesuai dengan tingkat penguasaan kompetensi masing-masing peserta didik, (skor individu).

Skor Individu (SI) :

SI = Skor Aspek K+SkorAspek A+Skor Aspek

Keterangan:

Skor Aspek K (Kognitif) $=(30 \%) *($ Jumlah Nilai/Nilai Maksimum Aspek $\mathrm{K})$

Skor Aspek A ( Afektif) $=(35 \%) *($ Jumlah Nilai/Nilai Maksimum Aspek A)

Skor Aspek P (Psikomotorik) $=(35 \%) *$ (Jumlah Nilai/Nilai Maksimum Aspek P)

Pembelajaran efektif terjadi bila siswa dapat memberikan tanggapan secara aktif, dapat mencapai kompetensi sesuai tujuan pembelajaran yang diukur melalui pencapaian kompetensi, dan secara klasikal dapat dicapai minimal 80\% memperoleh kompetensi secara individu dengan skor 70 KMK (kriteria minimal kelulusan).

Tabel 8. Data Hasil Penilaian Kompetensi

\begin{tabular}{|c|c|c|c|c|c|}
\hline \multirow{2}{*}{ No. } & \multirow{2}{*}{$\begin{array}{l}\text { Subjek } \\
\text { Uji }\end{array}$} & \multirow{2}{*}{$\begin{array}{l}\text { Aspek } \\
\text { yang Dinilai }\end{array}$} & \multicolumn{3}{|c|}{ Hasil Penilaian } \\
\hline & & & $\mathrm{T}$ & $\mathrm{R}$ & M \\
\hline \multirow{3}{*}{1.} & \multirow{3}{*}{ SMKN 5 Makasar } & Kognitif & 98 & 82 & 90.5 \\
\hline & & Afektif & 95 & 75 & 91.6 \\
\hline & & Psikomotorik & 100 & 81 & 92.3 \\
\hline \multirow{3}{*}{2.} & \multirow{3}{*}{ SMKT Gowa } & Kognitif & 96 & 76 & 92.4 \\
\hline & & Afektif & 95 & 75 & 89.7 \\
\hline & & Psikomotorik & 99 & 81 & 93.3 \\
\hline
\end{tabular}

Rerata penilaian secara menyeluruh $=91,6$

Keterangan: $\mathrm{R}=$ Terendah, $\mathrm{T}=$ Tertinggi, $\mathrm{M}=$ Rerata 
Rangkuman hasil penilaian pencapaian kompetensi pada tiga aspek kognitif, afektif, dan psikomotorik dijelaskan seperti berikut. Hasil pencapaian kompetensi pada dua sekolah sebagai subjek coba dalam pelaksanaan uji diperluas, yaitu 30 orang siswa di SMKN 5 dan 29 siswa di SMKT Gowa (lihat Brodie \& Irving, 26). Secara umum, jika diperhatikan pencapaian nilai dari dua sekolah telah memperoleh skor secara meyeluruh dengan nilai rerata $=91,5$. Jika diuraikan berdasarkan perolehan rerata nilai ke masing-masing subjek coba, siswa di dua sekolah subjek coba memperoleh nilai rerata di atas nilai KMK.

\section{Pembahasan}

Berdasarkan data hasil penelitian, dapat disimpulkan bahwa model pembelajaran dan perangkat pembelajaran yang dikembangkan menunjukkan produk yang efektif dan praktis dipergunakan untuk pembelajaran praktik berbasis kompetensi pada bidang keahlian instalasi listrik di SMK.

Efektifitas pembelajaran adalah standar atau taraf tercapainya tujuan pembelajaran dengan rencana yang telah ditetapkan sebelumnya. Sejalan dengan pendapat Charles Prosser, yaitu bahwa pada pendidikan kejuruan prinsip pendekatan pembelajaran efektif jika:(1) siswa dilatih sesuai lingkungan kerja dan diperkenalkan dengan situasi nyata untuk berfikir, berperasaan, berperilaku; (2) pengalaman latihan yang dilakukan secara teratur untuk membentuk kebiasaan bekerja dan berfikir meningkatkan prestasi kerja; dan (3) diajar oleh guru yang telah memiliki metode, pengalaman dan berhasil di dalam menerapkan pengetahuan, keterampilan dalam pembelajaran (Wardiman, 1998:38).

Indikator kompetensi yang telah dikembangkan dalam profil SKKD pemasangan instalasi listrik bangunan sederhana adalah bagian penting dalam perancangan kurikulum berbasis kompetensi. Hal tersebut memperkuat komponen perangkat pembelajaran yang menjadi produk penelitian pengembangan pembelajaran berbasis kompetensi, seperti modul, RPP, media, rubrik penyekoran. Selain itu, juga didukung dengan hasil penelitian Samsudi (2014: 313) bahwa aspek yang perlu mendapatkan pengembangan dalam pembelajaran program produktif adalah materi pembelajaran, metode, dan penilaian.

Pembelajaran program produktif di SMK pada dasarnya bersifat dual-based, yakni pembelajaran di sekolah dan penguatan di dunia usaha. Oleh karena itu, penyusunan profil SKKD di atas adalah untuk memberikan informasi dalam pengembangan program pembelajaran berbasis kompetensi dunia kerja, sesuai standar kompetensi berdasarkan keputusan No. KEP. 170/MEN/IV/2007.

Sehubungan dengan pengembangan model dan perangkat pembelajaran berbasis kompetensi bidang kelistrikan, pedoman pengembangannya tidak terlepas pada teori dan pendapat beberapa ahli seperti Wardiman (1998: 33-35), bahwa pendidikan kejuruan adalah pendidikan yang mempersiapkan peserta didik untuk memiliki kemampuan bekerja dan mempersiapkan secara langsung satu pekerjaan, bertujuan membantu peserta didik mengembangkan potensinya ke arah suatu pekerjaan atau karir sesuai kebutuhan dunia kerja.

Berdasarkan teori dan pendapat para ahli di atas, pengembangan pembelajaran berbasis kompetensi, mengacu pada SKKD pemasangan instalasi listrik bangunan sederhana. Hasil identifikasi kebutuhan kompetensi yang dilakukan dalam workshop dengan praktisi lapangan anggota AKLI Cabang Makassar dan melalui FGD dengan praktisi pendidikan, GuruGuru SMK dan Dosen D3 bidang kelistrikan. Sejalan dengan aturan No.251/C/KEP/MN/ 2008 tentang setiap kompetensi keahlian yang diperlukan, SMK dapat mengkhususkan kompetensi sesuai dengan tuntutan kebutuhan dunia kerja terkait (konsentrasi keahlian) dengan tidak mengabaikan kemampuan dasar kompetensi.

Prinsip pengembangan perangkat pembelajaran berbasis kompetensi dilakukan mengacu pada pendapat Munthe (2009:30), bahwa dalam mendesain pembelajaran harus dikontekstualisasikan dengan indikator kompetensi, 
memahami sintaks pembelajaran dan penilaiannya mengacu pada pencapaian tiga aspek kognitif, afektif dan psikomotorik.

Implementasi produk penelitian dilakukan melalui uji produk di sekolah, dengan menggunakan pendekatan pembelajaran kontekstual atau Contextual Teaching Learning (CTL). Nurhadi (2004:13) bahwa CTL adalah konsep belajar dengan menghadirkan situasi dunia nyata ke dalam kelas dan mendorong siswa menghubungkan dan menerapkan pengetahuan yang dimiliki dengan kehidupan seharihari. Pembelajaran kontekstual artinya isi atau materipembelajaran terintegrasi dengan keadaan masa kini, situasi dalam masyarakat diangkat dalam pembelajaran di kelas,

Keberhasilan uji perangkat pembelajaran, menunjukkan gambaran kecendrungan peningkatan hasil secara keseluruhan terhadap aktivitas guru dan siswa selama berlangsungnya uji kelompok kecil dan uji diperluas, baik dari aspek keterlaksanaan tahapan pembelajaran (sintaks pembelajaran) maupun pada perangkat pembelajaran yang dikembangkan. Pencapaian kompetensi pada siswa diukur melalui penilaian rubrik pada aspek kognitif, afektif dan psikomotorik. Pencapaian nilai siswa dari masing-masing subjek coba, secara meyeluruh memperoleh nilai rerata di atas nilai KMK.

\section{PENUTUP}

Berdasarkan hasil penelitian dan pengembangan model pembelajaran berbasis kompetensi terintegrasi pendidikan karakter pada bidang kelistrikan, ditemukan model dan perangkat pembelajaran yang efektif dipergunakan pada pembelajaran di SMK. Hal itu ditunjukkan oleh hal-hal sebagai berikut. Pertama, perbandingan nilai rerata antara SMKN 5 dan SMKT cukup signifikan. Hal ini memberikan gambaran bahwa pencapaian kompetensi dalam proses pembelajaran yang dipergunakan secara keseluruhan hampir sama dan sangat tinggi. Guru memberi skor penilaian melalui pencapai kompetensi sesuai kriteria dalam penyekoran rubrik terhadap ketiga aspek kompetensi, yaitu aspek kognitif, aspek afektif dan aspek psikomotorik.
Penilaian keefektifan pembelajaran secara menyeluruh menunjukkan bahwa siswa dan guru memberikan tanggapan secara aktif sehingga dapat mencapai tujuan pembelajaran diukur melalui pencapaian kompetensi, yang dicapai siswa di dua sekolah dengan memeroleh nilai tinggi. Kedua, hasil analisis kebutuhan kompetensi kelistrikan melalui workshop yang melibatkan pihak para ahli pekerjaan spesifik kelistrikan yang dilanjutkan dengan FGD bersama guru untuk mengidentifikasi kebutuhan pembelajaran di sekolah dan dapat dirumuskan profil standar kompetensi (SK) dan kompetensi dasar (KD) memasang instalasi listrik bangunan sederhana. Ketiga, dapat dihasilkan Prototipe Model Pembelajaran dan Instrumen Penilaian, termasuk perangkat pembelajaran evaluasi hasil belajar (Penyekoran Rubrik). Keempat, hasil uji coba memperlihatkan bahwa siswa dan guru memberi apresiasi yang baik terhadap penerapan model pembelajaran yang dikembangkan. Kelima, ada kecendrungan peningkatan aktivitas guru dan siswa selama berlangsungnya uji coba. Keenam, ada kecenderungan peningkatan kompetensi sehingga dapat disimpulkan bahwa hasil pembelajaran meningkat dan tujuan pembelajaran tercapai secara.

\section{UCAPAN TERIMA KASIH}

Ucapan terima kasih disampaikan kepada Prof. Sukamto, Ph.D. dan Prof. Pardjono, $\mathrm{Ph} . \mathrm{D}$. selaku promotor yang memberikan bimbingan, arahan, dan masukan dalam penulisan disertasi. Ucapan terima kasih yang sama disampaikan kepada Prof. Dr. H. Husain Syam, M.TP., selaku Dekan Fakultas Teknik dan Prof. Dr. H. Jufri, M.Pd., selaku Ketua Lembaga Penelitian UNM yang sudah memberi kesempatan dan memfasilitas peneliti selama dua tahun, dalam mengajukan dan mengembangkan penelitian hibah bersaing pada Ditlitabmas Ditjen Dikti. 


\section{DAFTAR PUSTAKA}

Borg, W.R. \& Gall, J.P. 1983. Educational Research: an Introduction. Seventh Edition. New York: Pearson Education, Inc.

Brodie, P. \& Irving K. 2006. "Assessment in Work-Based Learning: Investigating a Pedagogical Approach to Enhance Student Learning." Journal of Assessment and Evaluation.

Dick, Walter, Carey, Lou, \& Carey James O. 2005. The Systematic Design of Instruction.Boston: Allyn and Bacon, Permissions Departemen.

Direktorat Ketenagaan Dirjen Dikti Depdiknas. 2008. Pengembangan dan Peningkatan Kualitas Pembelajaran.

Djojonegoro, Wardiman. 1998. Pengembangan Sumber Daya Manusia melalui SMK. Jakarta: PT. Jayakarta Agung Offset.

Finch R. Curtis., Crunkilton R. John. 1999. Curriculum Development in Vocational and Technical Education: Planning, Content, and Implementation. London: Allyn and Baccon.
Muchith, S. 2008. Pembelajaran Kontekstual. Semarang: RaSAIL Media Group.

Munthe, B. 2009. Desain Pembelajaran. Yogyakarta : Pustaka Insan Madani.

Nurhadi. 2004. Pembelajaran Kontekstual dan Penerapannya dalam KBK. Malang: Universitas Negeri Malang Press.

Saifuddin, Azwar. 2010. Sikap Manusia Teori dan Pengukurannya. Yogyakarta: Pustaka Pelajar.

Samsudi. 2014. "Pengembangan Model Pembelajaran Program Produktif SMK untuk Membentuk Karakter Kewirausahaan Lulusan". Jurnal Cakrawala Pendidikan, Th. XXXIII, No. 2. Juni 2014.

Sukmadinata, N.S. 2008. Metode Penelitian Pendidikan. Bandung: PPs UPI dan Remaja Rosdakarya. 